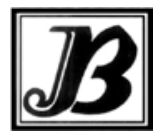

J. Bio-Sci. 27: 143-148, 2019

ISSN 1023-8654

http://www.banglajol.info/index.php/JBS/index

DOI: https://doi.org/10.3329/jbs.v27i0.44679

\title{
OPTIMIZATION OF THE CONDITION OF PHYTOSTEROL EXTRACTION CONDITIONS FROM MICROALGAE NANNOCHLOROPSIS USING ETHANOL OF DIFFERENT PURITY LEVELS
}

\author{
D Fithriani and Nurhayati* \\ Research Centre for Marine and Fisheries Product Processing and Biotechnology \\ JI KS Tubun, Petamburan VI, Jakarta, Indonesia
}

\begin{abstract}
Phytosterols are plant sterols, included in secondary metabolite compounds and have broad benefits in the health field. This study aims to observe the effect of ethanol solvency purity, time of extraction on phytosterol content. The extraction was carried out by saponification using a $7.5 \% \mathrm{KOH}$ solution in ethanol. The variations in extraction time are 1, 2, 3, and 4 hours. Ethanol used varies purity levels, i.e technical $70 \%$, technical $96 \%$, and pure analysis. The variations in maceration time are 1, 2 and 3 days. The results showed that all ethanol solvents with different purity levels resulted in the highest crude phytosterol under long duration of 1 hour extraction time. The ethanol purity rate had a significant effect on the yield of phytosterol produced, i.e., $70 \%$ technical, $96 \%$ technical, and pure analysis consume $0.4 \%, 1.63 \%$ and $4.19 \%$ crude phytosterol, respectively.
\end{abstract}

Key words: Extraction, Phytosterol, Nannochloropsis

\section{Introduction}

Phytosterols are sterols that are naturally derived from plants. Chemically, phytosterols are similar to those obtained from animals. Sterols consist of three combinations of cyclohexane rings with various sterols $>40$ phytosterols). Phytosterols consist of 28 to 30 atoms with steroids as structural framework with hydroxyl groups attached to C-3 of the A ring, and an aliphatic chain on C-17 atoms of the D ring (Pateh et al. 2009). More than 100 types of phytosterols have been reported in plants, but the most abundant are sitosterol, stigmasterol and campesterol (Berger et al. 2004, Kritchevsky and Chen 2005).

Recent years have done a lot of research on the role of phytosterol in various aspects of health. Phytosterols are thought to lower cholesterol in the blood, and are used in the industries of progesterone, corticoids, estrogens, contraceptives, diuretics, male hormones and vitamin D (Cabral and Fernandes 2007, Sukmaniah et al. 2008). With the widespread fitosterol market, many studies have focused on identifying new natural resources for phytosterols and several studies have shown that microalgae are an appropriate alternative source of these functional compounds (Francavilla et al. 2012).

Nannochloropsis sp. better known as the Sea Chlorela is a microalga belonging to the class of Eustigmatophyceae. These microalgae are about 1-2 $\mu \mathrm{m}$ in size and grow optimally in the waters with salinity 25-35 ppt, temperature $25-30^{\circ} \mathrm{C}, \mathrm{pH} 8-9$ and light intensity $1000-10000$ lux (Isnansetyo and Kurniastuty 1995). Nannochloropsis commonly used in the field of aquaculture that is as a feed larvae, small fish and

*Author for correspondence: n_hay04@yahoo.com 
crustase. Excess Nannochloropsis include high nutrient content, easily cultured en masse, rapid growth, nontoxic, and contain antibiotic compounds (Fulk and Main 1991). Sterol is one of the important components found in the eukaryotic cell membrane (Volkman et al. 1998). Sterols are present in microalgae cell membranes that act as biomarkers to identify organic matter in the environment (Volkman et al. 1998).

Extraction of phytosterols can be performed by means of saponification method using ethanol solvent in $\mathrm{KOH}$ (Kim et al. 1990, Xiao et al. 2013). This study aims to see the effect of ethanol solvency purity and time of extraction on phytosterol content.

\section{Materials and Methods}

\section{Chemical and equipment}

Nannochloropsis sp., KOH, aquades, n-hexane and ethanol (pure analysis, technical 96\%, and technical $70 \%$ were used for this study. As equipment glass container, reflux, centrifuge, evaporator, sonicator, and TLC scanner (CAMAG TLC Scanner 3 CAT No. 027.6485 SER. No. 160602) were used.

\section{Methods}

\section{Analysis of proximate compositions}

For analysis ash, water, fat, and protein content refers to SNI 01-2354 (1-4) - 2006 (BSN 2006 a,b,c\&d). Analysis of carbohydrate and coarse fiber content refers to Apriyantono et al. (1989).

\section{Preparation extract}

A total of $5.0 \mathrm{~g}$ of Nannochloropsis microalgae was added with $50 \mathrm{ml}$ of $7.5 \% \mathrm{KOH}$ solution in ethanol and then in sonication for 1 hour. Furthermore, the mixture in reflux with heating treatment duration $(1,2,3$, and 4 hours) was then left to 1 night. The separation of the filtrate from the precipitate is carried out by centrifugation $\left(4000 \mathrm{rpm}, 10 \mathrm{~min}, 10^{\circ} \mathrm{C}\right)$. Partition of the extract was carried out by addition of $\mathrm{n}$-hexane (2: 1 $\mathrm{v} / \mathrm{v}$ ), followed by water addition until the $\mathrm{n}$-hexane fraction reached $\mathrm{pH} 7.0$. The obtained $\mathrm{n}$-hexane fraction was then evaporated using an evaporator and dried using a concentrator.

\section{Phytochemical screening test}

For phytochemical screening tests performed include alkaloids, saponins, tannins, phenolics, flavonoids, triterpenoids, steroids were used for this study.

\section{Test levels of B-sitosterol and B-carotene}

The test was done using TLC Sanner tool. The bottling of the $6 \mathrm{~mm}$-wide strip test solution was conducted semi-quantitatively using Linomat on a TLC plate that had been heated in an oven for 7 minutes at a temperature of $100^{\circ} \mathrm{C}$. Bottling is done with a distance of $1 \mathrm{~cm}$ from below, $1 \mathrm{~cm}$ from the right and $1 \mathrm{~cm}$ from the left of the KLT plate. The bottling rate was $50 \mathrm{~nL} / \mathrm{s}$. Vessel saturation is done for 30 minutes. Distance of development is $8 \mathrm{~cm}$. The resulting development plate is scanned with a TLC scanner. 


\section{Results and Discussion}

\section{Proksimat composition of Nannochloropsis oculata}

Table 1. Proportional composition of Nannochloropsis oculata microalgae

\begin{tabular}{cc}
\hline Proximate compositions & Yield (\%) \\
\hline Moisture & $14.82 \pm 0.12$ \\
Ash & $39.36 \pm 0.07$ \\
Carbohydrate & $4.36 \pm 0.04$ \\
Proteins & $29.06 \pm 0.46$ \\
Lipids & $4.29 \pm 0.41$ \\
\hline
\end{tabular}

The proximate composition of the $N$. oculata microalgae was or are shown in Table 1. N. oculata had high ash and protein content, $39.36 \%$ and $29.06 \%$. While carbohydrate and fat content had a low value of 4.365 and $4.29 \%$. This N. oculata proximate composition is lower than that of an earlier study by Sorgeloos (1996) who reported that the protein content of Nannochloropsis sp. by $37 \%$, carbohydrates $18 \%$ and fat $7.8 \%$. Similarly, the study of Sanjeewa et al. (2016) who reported that N. oculata had a protein content of 30.52\%, $30.64 \%$ ash, and $7.99 \%$ fat. However, the differences of nutrient values in microalgae might be influenced by the growing environment such as $\mathrm{pH}$, salinity, temperature, and light intensity.

\section{Rendement of crude phytosterol}

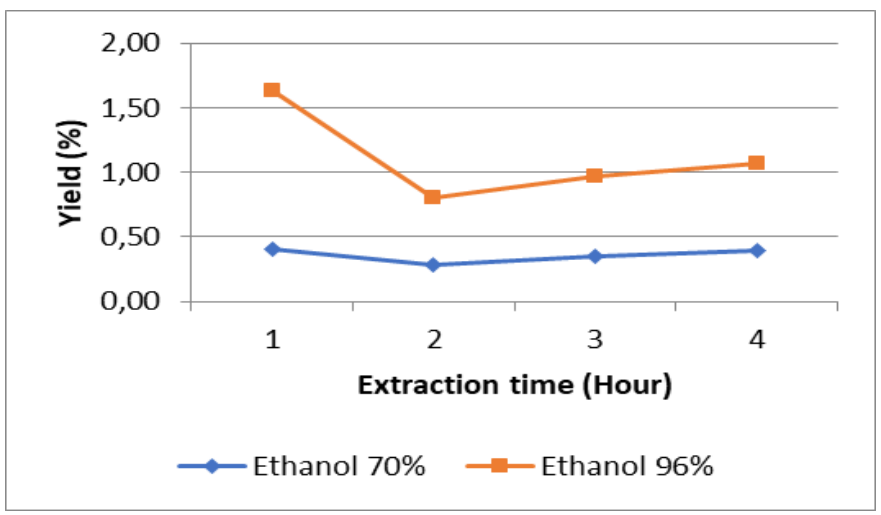

Fig. 1. Rendement of crude fitosterol from N. oculata.

The value of crude phytosterol rendement from N. oculata is shown in Fig. 1. The use of ethanol with higher purity level results in higher tenement value. Phytosterols are known to dissolve in organic solvents and most solvents have one alcohol functional group (Kanimozhi and Bai 2012). The lower the purity level of the alcohol used, the more water contained in the solvent. The higher water content will cause the low solubility of non-polar compounds such as phytosterols. Thus, the level of phytosterol produced will also be lower. 
Meanwhile, in the long treatment time of extraction showed that the highest rendement value was obtained at 1 hour of extraction, except with the optimum ethanol $96 \%$ solvent utilization at 2 hours of extraction.

\section{Phytochemical screening analysis of crude phytosterol}

Components contained in crude fitosterol are analyzed by their compounds in a qualitative manner using color test tests with several reactions including alkaloid compounds, saponins, tannins, phenolic, flavonoids, triterpenoids, steroids and glycosides. The results of phytochemical screening of crude fitosterol from $\mathrm{N}$. oculata are presented in Table 2.

Table 2. Phytochemical screening test results of crude phytosterol

\begin{tabular}{ccc}
\hline Phytochemical & \multicolumn{2}{c}{ Crude phytosterol } \\
\cline { 2 - 3 } & Ethanol 70\% & Ethanol 96\% \\
\hline Alkaloid & + & + \\
Saponin & - & + \\
Tannin & - & - \\
Phenolik & + & - \\
Flavonoid & + & + \\
Triterphenoid & - & + \\
Steroid & + & + \\
Glykoside & + &
\end{tabular}

The results of phytochemical screening indicate a treatment that results in negative triterpenoids and steroids. Though phytosterol compound itself is shown with positive results on triterpenoid and steroid tests. In addition, screening did not show a uniform result. This may be due to the very small number of samples so that detection is extremely difficult. According to Pascal and Segal (2006), phytosterols consist of five forms, namely as free alcohol, fatty acid esters, sterile glycosides, sterilized glycosides terasilasi, and acid esters. Thus, phytosterols will positively contain triterpenoids, phenolic, steroids, and glycosides.

\section{Analysis of B-carotene, B-sitosterol, and stigmasterol levels}

Beta sitosterol has many health benefits. It is known that beta sitosterol is found naturally in vegetables and fruits, but the ingredients are too low to provide a medicinal effect. 
Table 3. Levels of B-carotene, B-sitosterol, and stigmasterol per weight of crude fitosterol

\begin{tabular}{lcccc}
\hline Parameter & \multicolumn{2}{c}{$\begin{array}{c}\text { Yield per weight of crude phytosterol } \\
\text { extract (\%) }\end{array}$} & $\begin{array}{c}\text { Yield per weight of microalgae (g/kg } \\
\text { microalgae) (\%) }\end{array}$ \\
\cline { 2 - 5 } & Ethanol 70\% & Ethanol $96 \%$ & Ethanol 70\% & Ethanol $96 \%$ \\
\hline B-carroten & 6.14 & 2.74 & 0.25 & 0.45 \\
B-sitosterol & 10.99 & 6.44 & 0.44 & 1.05 \\
Stigmasterol & 21.58 & 17.53 & 0.87 & 2.86 \\
\hline
\end{tabular}

\section{Conclusion}

Microalgae Nannochloropsis oculata might be used as an alternative source of phytosterol raw materials. The use of $96 \%$ technical ethanol resulted in higher rendement of crude phytosterols compared to the use of $70 \%$ technical ethanol. While the long treatment time of extraction yielded optimum yield at 1 hour reaction with higher levels of B-carotene, B-sitosterol, and stigmasterol in $96 \%$ ethanol use compared to $79 \%$ ethanol.

\section{References}

Apriyantono A, Fardiaz D, Puspitasari N L, Yasni S and Budiyanto S (1989). Petunjuk praktikum analisis pangan. Bogor: PT IPB Press.

Berger A, Jones PJH and Abumweis SS (2004). Plant sterols: factors affecting their efficacy and safety as functional food ingredients. Lipids Health Dis., 3: 5-23.

BSN (2006a). SNI 01-2354.1-2006. Cara uji kimia - Bagian 1: Penentuan kadar abu pada produk perikanan. Jakarta: Badan Standardisasi Nasional.

BSN (2006b). SNI 01-2354.2-2006. Cara uji kimiaBagian 2: Penentuan kadar air pada produk perikanan. Jakarta: Badan Standardisasi Nasional.

BSN (2006c). SNI 01-2354.3-2006 . Cara uji kimia - Bagian 3: Penentuan kadar lemak total pada produk perikanan. Jakarta: Badan Standardisasi Nasional.

BSN (2006d). SNI 01-2354.4-2006. Cara uji kimia - Bagian 4: Penentuan kadar protein dengan metode total nitrogen pada produk perikanan. Jakarta: Badan Standardisasi Nasional.

Cabral JMS and Fernandes P (2007). Phytosterols: Applications and recovery methods. Bioresource Technology, 98: $2335-2350$

Fulks W and Main KL (1991). The design operations of commercial - Scale Live Feeds Production System Rotifers and Mikroalgae Cultur System. Proceeding of a U.S. - Asia Workshop. Edited by Wendy Fluks and Kevan L. Main. The Ocean Institute Hawaii. 
Francavilla M, Colaianna M, Zotti M, Morgese MG, Trotta P, Tucci P, Schiavone S, Cuomo V and Trabace L (2012). Extraction, Characterization and In Vivo Neuromodulatory Activity of Phytosterols from Microalga Dunaliella Tertiolecta. Current Medicinal Chemistry. 19:3058-3067.

Hartmann MA (1998). Plant sterols and the membrane environment. Trends Plant Sci., 3:170-175.

Isnansetyo A and Dan Kurniastuty (1995). Teknik Kultur Phytoplankton Zooplankton. Pakan Alam untuk pembenihan organism laut. Yokyakarta: Kanisius. http://kin.perpusnas.go.id/.

Kanimozhi D and Bai VR (2012). Evaluation of phytochemical antioxidant antimicrobial activity determination of bioactive components of ethanolic extract of aerial and underground parts of Cynodon dactylon L. International Journal of Scientific Research and Reviews, 1(2): 33.

Kim SH, Park SH, Ahn BG, Yi JS, Park MS, Lee BR and Kim K (1990). Extraction and determination of phytosterols from corn oil foots. Archives of Pharmacal Research, 13(3): 282-284.

Kritchevsky D and Chen SC (2005). Phytosterols-health benefits and potential concerns: a review. Nutr. Res., 25: 413428.

Pascal SL and Segal R (2006). Phytosterols-Biological active compounds in food. Journal of Agroalimentary Processes and Technologies, 7(1):149-158.

Pateh UU, Haruna AK, Garba M, Iliya I, Sule IM, Abubakar MS and Ambi AA (2009). Isolation of stigmasterol, $\beta$ sitosterol, and 2-hydroxyhexadecanoid acid methyl ester from rhizomes of Stylochiton lancifolius. Nig. Journ. Pharm. Sci. 8(1): 19-25.

Sanjeewa KKA, Fernando IPS, Samarakoon KW, Lakmal HHC, Kim EA, Kwon ON, Dilshara MG, Lee JB and Jeon YJ (2016). Anti-inflammatory and anti-cancer activities of sterol rich fraction of cultured marine microalga Nannochloropsis oculata. Algae, 31(3): 277-287.

Sukmaniah S, Bardosono S, Oetoro S, Permadhi I, dan Lestarina L (2008). The effects of phytosterol in low fat milk on serum lipid levels among mild moderately hypercholesterolemic subjects. Med J. Indones, 17(1): 5-12.

Volkman JK, Barrett SM, Blackburn SI, Mansour MP, Sikes EL and Gelin F (1998). Microalgal biomarkers: a review of recent research developments. Org. Geochem., 29:1163-1179.

Xiao XH, Yuan ZQ and Li GK (2013). Preparation of phytosterols and phytol from edible marine algae by microwaveassisted extraction and high-speed counter-current chromatography. Separation and Purification Technology, 104: 284-289. 